\title{
La sabiduría de Jesús y Cristo Sabiduría
}

\section{Rafael Aguirre, Universidad de Deusto-Bilbao, España.}

La tradición sapiencial es, quizá, la menos presente en la conciencia del pueblo cristiano y, sin embargo, recorre toda la historia de Israel, desde los círculos que rodeaban a los monarcas, cuando se instauró el Estado, hasta los tiempos lindantes con el Nuevo Testamento. Es un tipo de reflexión que siempre existió en Israel y, por eso, los libros sapienciales proceden de épocas muy diversas. Por otra parte, es una tradición de singular profundidad, variedad y riqueza'. La tradición sapiencial dialoga con la cultura de su tiempo, presenta una reflexión de hondo valor humanista, muy dispar por cierto, porque en algunos casos asume la sabidurfa convencional, como en Proverbios, mientras que en otros la desbarata, como en el libro de Job o el Eclesiastés. Es también una tradición que abre perspectivas nuevas en la fe de Israel, como la reflexión sobre el mal o los rasgos femeninos de la Sabiduría.

En este artículo voy a presentar - de forma breve y sin pretensiones de agotar un tema inmenso- la referencia a Jesús de esta tradición sapiencial. El título señala ya la doble perspectiva, en que se mueve el trabajo.

1. Jesús, judío fiel toda su vida, a quien llaman "maestro" y cuya sabidurfa sorprende con frecuencia, se inscribe en la tradición de los sabios de Israel, de forma peculiar, ciertamente.

2. Sus primeros seguidores pospascuales - judíos también ellos - van a interpretar muy pronto a Jesucristo a la luz de la Sabiduría de Dios, como la manifestación, sumamente paradojica, de la mencionada Sabiduría. En Jesucristo desemboca la tradición sapiencial judía, pero, a la vez, esta tradición es reinterpretada radicalmente, quizá como ninguna otra, a la luz de la vida de Jesús.

1. En español una magnifica introducción a esta literatura en V. Morla, Libros sapienciales y otros escritos, Estella, 1994. Existe traducción de la importante obra de G. von Rad, Sabiduria en Israel, Madrid, 1985. 


\section{La sabiduría de Jesús}

\subsection{Jesís en la tradición de los sabios de Israel}

Aunque no deseo hacer una exposición academicista, considero conveniente comenzar con un apunte informativo. En la actualidad se multiplican de forma creciente los estudios sobre el Jesús histórico, y en muchos de ellos, a diferencia de lo que sucedía hace unos años, se subraya mucho que Jesús era un sabio.

En efecto, ha preponderado la visión de Jesús como profeta, que anunciaba el reino de Dios como una realidad futura, inminente, lo que promovía una actitud de tensa espera y un gran radicalismo moral. Hoy, por el contrario, muchos estudiosos presentan a Jesús como un sabio, en el sentido de que habla del reino de Dios no como de una realidad futura, sino ya presente y que nos invita a ver y valorar la realidad de una forma distinta y alternativa a la convencionalmente establecida en el mundo. Muy frecuentemente, estos estudiosos actuales consideran que tlonde mejor podemos encontrar al Jesús histórico es en la famosa fuente $Q$, una colección de dichos o sentencias de Jesús, sin contexto narrativo, conocida por Lucas y Mateo, pero de la que no dispuso Marcos. Esta fuente $Q$ tenía una organización coherente, que se puede descubrir con una minuciosa comparación entre Mateo y Lucas, así como una teología propia, una de cuyas características principales sería, precisamente, la presentación de Jesús como sabio y como la Sabiduría personificada ${ }^{2}$.

Hay autores que dan un paso más y creen encontrar en Jesús un notable parecido con los filósofos cĺnicos de aquel tiempo. Por supuesto que hay que quitar a la palabra "cínico" todo el sentido peyorativo que pueda tener en el lenguaje actual y entenderla en sentido técnico. El cinismo era un movimiento filosófico, que nació en el siglo IV a. C. y que estaba en un momento floreciente, en el tiempo imperial, el que afecta a nuestro estudio. Era una filosoffa muy extendida popularmente, de marcado carácter contracultural, respecto al estilo de vida helenizado y lujoso que se desartollaba en las ciudades y de orientación práctica. Entre los muchos dichos cínicos que se pueden presentar ${ }^{3}$ me limito a

2. La literatura sobre $Q$ es ingente, pero hay una obra que ejerce en la actualidad una gran influencia: J. Kloppenborg, The Formation of $Q:$ Trajectories in Ancient Wisdom Collection, Philadelpia, 1987. Este autor defiende que en $Q$ hay un primer estrato con una teologia puramente sapiencial y en el que se habla del reino de Dios presente. Pero hay también un segundo estrato, literariamente posterior, lo que no prejuzga su mayor o menor valor histórico, de carácter apocalíptico y que habla de Jesús como del Hijo del Hombre y del futuro reino de Dios. El apocrifo Evangelio de Tomás se caracteriza por ser también una colección de sentencias de Jesús, con características sapienciales, pero sin rasgos apocalipticos.

3. F. G. Downing, Christ and the Cynics, Sheffield, 1988, hace una presentacion amplisima de textos tenidos por cínicos, y señalando sus parentescos neotestamentarios. Es 
citar uno, de Antístenes, transmitido por Diógenes Laertio: "como le criticaran una vez por el hecho de tratar con gente de mal vivir dijo: también los médicos andan en compañía de los enfermos, pero no tienen fiebre"4. Inmediatamente se nos viene a la mente el dicho de Jesús, en Marcos 2, 17 y paralelos.

De la existencia de estas semejanzas indudables no se puede deducir que hubiese contacto ni relación de Jesús con los filósofos cínicos; y, sobre todo, su enseñanza tiene una raíz muy diferentes.

Jesús era tenido por sabio y maestró. Se le llama así muchas veces. Lo hacen los discípulos (Mc 4, 38; 9, 38; 10, 35; 13, 1), la gente (Mc 5, 35; 9, 17; 10, 17) y los adversarios (Mc 12, 14.19). Tenía, como los maestros del tiempo, un grupo de discípulos, a los que enseñaría sus doctrinas, y éstos las memorizarían como era habitual en aquella cultura. Aún es fácil encontrar en los evangelios numerosos dichos, a veces mediante la retraducción al arameo, en los cuales se perciben señales características de las técnicas de la memorización y la transmisión oral.

El lenguaje de Jesús sabio o maestro tiene unas características precisas. Con frecuencia es un lenguaje poético ${ }^{7}$. Esta afirmación puede resultar rara y chocante, porque estamos muy acostumbrados a una mentalidad teológica, unilateralmente racionalista, que pretende encerrar las enseñanzas de Jesús en sistemas doctrinales coherentes y cerrados, y en códigos legales precisos. Pero el lenguaje de Jesús desborda todo esto. Habla en metáforas, con imágenes, con expresiones normalmente breves, incisivas, penetrantes, que resuenan en lo más profundo del ser humano y que se quedan fácilmente grabadas en el corazón. El lenguaje de los teólogos, por muy actual que sea en su tiempo, pasa con rapidez y de modo inevitable, porque está muy condicionado culturalmente, pero el lenguaje de Jesús queda, se sigue repitiendo a través de los siglos, sin que pierda su vigor, porque la poesía tiene una gran capacidad transcultural, precisamente, porque surge y se dirige a lo más hondo de la experiencia humana.

La verdadera poesía no es un mero revestimiento pedagógico, ni un procedimiento para llegar a la gente sencilla. La poesía es la expresión natural de las

un libro útil, pero como sucede con esle elenco de paralelos, el inconveniente es la descontextualización de los pasajes cilados, el problema de su cronología y el carácter cínico o no (por ejemplo, estoico) de muchos de ellos.

4. La obra de Diógenes Laertio se encuentra con una buena introducción en C. García Gual, La secta del perro. Diógenes Laertio, Vidas de los filosofos cínicos, Madrid, 1987. El dicho citado es D.L. 6, 6.

5. Puede verse mi artículo "Nuevo Testamento y helenismo. La teoría de Jesús como un predicador cínico", EstBib LXI (2003), pp. 3-25.

6. R. Riesner, Jesus als Lehrer, Tübingen, 1981; P. Perkins, Jesuls como maestro, Córdoba, 2001.

7. J. L. Espinel, La poesía de Jesís, Salamanca, 1986. 
más hondas experiencias humanas. Los grandes místicos son grandes poetas, porque su profunda experiencia de Dios no cabe en el lenguaje de la vida cotidiana, y por eso recurren a imágenes, metáforas e hipérboles; fuerzan y recrean el lenguaje para expresar lo que experimentan como lo más hondo, lo más real, pero ante lo que las palabras son balbuceos totalmente insuficientes; el descubrimiento del amor, la conmoción ante la belleza, la experiencia de Dios... requiere o, quizá mejor, suscita el espíritu poético.

Se suelen identificar en el Jesús sabio el recurso de diversas figuras literarias, algunas de las cuales señalo.

Proverbios, dichos basados en la experiencia, que transmiten una sabiduría secular, que corrían de boca en boca por el pueblo. "Lo que quieran que les hagan los hombres, háganselo ustedes a ellos", "no necesitan médicos los sanos, sino los enfermos". Jesús utilizó proverbios del acerbo cultural de su pueblo.

Una clase muy especial de proverbios son los aforismos, que se caracterizan por ser socialmente incorrectos, contraculturales y provocativos. Son muy frecuentes en Jesús. "Es más fácil que un camello pase por el ojo de una aguja que un rico entre en el reino de Dios". La teología rabínica consideraba normalmente que la riqueza y la abundancia de bienes materiales eran un signo de la bendición divina. El dicho de Jesús, un aforismo provocativo, es una hipérbole y, por tanto, no hay que tomarlo al pie de la letra, pero dice algo importante que si hay que tomarse muy en serio.

Jesús utilizó metaforas. Fijémonos en un texto joánico de sabor histórico:

El viento sopla donde quiere, y oyes su voz; pero no sabes de dónde viene, ni a dónde va. Así son los nacidos del Espíritu (Jn 3, 8).

En hebreo y en arameo una misma palabra, ruaj, sirve para designar al viento y al espíritu. El viento es símbolo del espíritu. La movilidad del viento, su velocidad, su presencia misteriosa y total, evidente pero invisible, poderosa y suave, incontrolable, son metáfora del Esplritu de Dios, de su forma de actuación. Es una metáfora que procede de la experiencia espiritual de Jesús y del contacto con la naturaleza. Es un hallazgo lingüístico genial para hablar del misterio, bellamente, sin cerrar sus posibilidades, dejándolas abiertas. Las parábolas de Jesús utilizan profusamente el lenguaje metafórico. Enseguida haremos alguna referencia a ellas.

El Jesús sabio aparece en lo que técnicamente se llaman los apotegmas de los evangelios. Son escenas breves, que culminan y están centradas en una frase redonda de Jesús: "den al César lo que es del César y a Dios lo que es de Dios", "no ha sido hecho el hombre para el sábado, sino el sábado para el hombre". En

8. J. L. Espinel, op. cir., pp. 243 s. 
muchas ocasiones, el pequeño marco narrativo es secundario, no histórico, y fue creado para enmarcar la enseñanza de Jesús.

\subsection{La enseñanza sapiencial de Jesús}

¿Cuáles son las enseñanzas sapienciales de Jesús? Comprenderá el lector inmediatamente que voy a hacer una selección, que aspiro no sea arbitraria, sino que nos lleve al centro de la enseñanza del sabio galileo.

Ante todo, Jesús habla de la bondad y de la cercanía de Dios, lo que da a la vida humana un talante de confianza y libertad radicales. Recordemos las palabras, quizá, más típicamente sapienciales de Jesús:

No anden preocupados por su vida, qué comerán, ni por su cuerpo, con qué se vestirán. ¿No vale más la vida que el alimento, y el cuerpo que el vestido? Miren las aves del cielo: no siembran, ni cosechan, ni recogen en graneros; $y$ su Padre celestial las alimenta. ¿No valen ustedes más que ellas?... Y del vestido, ¿por qué preocuparse? Observen los lirios del campo cómo crecen; no se fatigan ni hilan. Pero yo les digo que ni Salomón, en toda su gloria, se vistió como uno de ellos. Pues si a la hierba del campo que hoy es y mañana se echa al homo, Dios así la viste, ¿no lo hará mucho más con ustedes hombres de poca fe... (Mt 6, 25-33; Lc 12, 22-31).

No teman a los que matan el cuerpo, pero no pueden matar el alma; teman más bien al que puede llevar a la perdición alma y cuerpo en la gehenna. ¿No se venden dos pajarillos por un as? Pues bien, ni uno de ellos caerá en tierra sin el consentimiento de su Padre. En cuanto a ustedes, hasta los cabellos de su cabeza están todos contados. No teman, pues; ustedes valen más que muchos pajarillos (Mt 10, 28-31; Lc 12, 4-7).

Los dichos sapienciales de Jesús subrayan que de forma gratuita e inesperada se nos abre una puerta, a través de la cual penetra una luz que ilumina nuestras tinieblas, y se nos comunica la vida y el amor de Dios. Habla de un señor que vendrá de forma imprevista y entonces, cuando los siervos se apresten con urgencia a servirle, les dirá que no, que se sienten ellos porque será él, el Señor, quien desea lavarles los pies y servirles uno a uno, a todos. Es un señor que sólo sabe amar y nos enseña el servicio gratuito al hermano (Lc 12, 35-40).

Y es que a Jesús le gusta expresarse en parábolas, una de las cuales acabo de glosar. Las parábolas no son ejemplos para aclarar una enseñanza teórica, ya impartida. Más bien, las parábolas pretenden, a través de un relato ficticio, interpelar al oyente, darle que pensar, abrirle una nueva perspectiva sobre su propia vida y sobre la realidad. Propiamente hablando, las parábolas no requieren ser interpretadas; son ellas las que interpretan la realidad. 
El Jesús sabio recurre a las parábolas - algunas ya conocidas en su tiempocon gran maestría y en función de su peculiar experiencia de Dios. Las parábolas tienen, normalmente, un punto insólito y paradójico y ahí suele estar el chispazo, que obliga a cambiar de mentalidad y de vida. Es el caso de un patriarca oriental, siempre tan digno, tan en su lugar, que no pierde jamás su compostura, pero que cuando ve a los lejos a su hijo que regresa a casa, después de haber hecho lo peor que cabía en aquella cultura, peor que dilapidar la hacienda, arruinar la fama y honra de la familia, no se lo piensa dos veces y echa a correr para salir a su encuentro y cuando llega se funde en un abrazo con el hijo perdido, con quien le había avergonzado, y no le pregunta nada, ni le pide cuentas de nada, sino que le restituye en su condición de hijo como si nada hubiera pasado y organiza una gran fiesta para celebrarlo con toda la alegría. La pregunta y la protesta del hijo "fiel", el que había permanecido en casa, refleja la extrañeza que el comportamiento del padre de la parábola tenía que provocar, necesariamente, en aquella cultura. Pero da también la medida de la novedad de la experiencia de Dios, que Jesús comunica (Lucas 15).

O recordemos el caso de aquel hombre que pasea por un campo, en una mañana bella de primavera, y siente en el rostro la brisa matutina, al tiempo que contempla la belleza de la naturaleza. No echa nada en falta. Al contrario, disfruta de la tranquilidad, de la vista y del silencio del campo. Pero como se entere de que all, debajo de sus pies, en el campo por donde pasea, hay un tesoro escondido... Entonces, todo cambia. Es obvio que el tesoro no es un producto natural del campo, que alguien lo ha introducido, quizá con la secreta esperanza de alegrar la vida de quien diese con él. El caso es que el hombre de nuestro relato no lo duda, va corriendo a vender todo lo que tiene para comprar el campo aquel. Y lo hace "por la alegría" del descubrimiento que ha hecho, no lo siente en absoluto como un sacrificio oneroso o algo que le amargue la vida. Al contrario, el descubrimiento del tesoro es una buena noticia, inesperada, gratuita, señal inequívoca de que alguien lo ama y pone a su alcance lo que él jamás hubiese podido sospechar (Mt 13,44).

Para el sabio Jesús descubrir a Dios hace ver y valorar la realidad de una forma diferente y alternativa a la convencionalmente vigente; es una experiencia de alegria y de gozo, que cambia la vida.

Jesús recurre, de un modo muy especial, a una tradición de los sabios y maestros, de honda raigambre en lsrael, pero que también se encuentra en la sabiduría de otros pueblos: es el tema de los dos caminos que se le ofrecen al ser humano, el que lleva a la felicidad y a la vida, y el que lleva a la perdición y a la muerte?.

9. M. J. Borg, Jesus. A New Vision, San Francisco, 1987, pp. 97-124. 
Ancho es el camino y ancha es la puerta que lleva a la perdición y muchos son los que la siguen; angosto es el camino y estrecha la puerta que lleva a la vida, y pocos son los que la encuentran (Mt 7, 13-14; Lc 13, 24).

Aquí se manifiesta el Jesús que inculca la sabiduría de la vida, el saber vivir en el presente. ¿Pero cuál es el camino y la puerta estrecha; cuál el camino y la puerta angosta?

Hay que atender al conjunto de las palabras de Jesús y, más en concreto, al contexto mateano inmediato en que se encuentran, que es el Sermón del monte. Es claro que Jesús no está fustigando a los ateos, a los idólatras, a los adúlteros, a los tenidos por grandes pecadores. Más bien, Jesús se distancia de la sabiduría convencional, en nombre de una sabiduría nueva, paradojica y altemativa. En este contexto, Jesús ha proclamado las bienaventuranzas. Después, en las famosas antítesis del Capítulo 5, no ha hablado simplemente del no matar -esto se da por supuesto-, sino de los que insultan y denigran $(5,21-22)$; de los que hacen la ofrenda en el culto, pero están enemistados con su hermano $(5,23-24)$; se ha referido a los que se aprovechan de la ley del divorcio vigente, en aquella sociedad patriarcal $(5,31-32)$; a los que responden con violencia a la violencia, a los que aman a los amigos y odian a los enemigos $(5,38-48)$. Ha hablado de los que dan limosna, oran y ayunan - es decir, que está hablando de gente tenida por muy religiosa-, pero lo hacen con ostentación y buscando el honor y el reconocimiento social $(6,1-18)$. El camino de Jesús se presenta como una alternativa - minoritaria y, por eso, estrecha - ante el camino convencional y ancho de aquella sociedad. ¿Cuáles son los valores del estilo de vida del camino estrecho al que invita Jesús? Me voy a fijar en cuatro, ciertamente centrales, presentando la altemativa de Jesús. Obviamente, tengo que realizar un desarrollo breve, casi sólo insinuante, del tema.

En primer lugar, la institución central de aquelia sociedad era la familia patriarcal, cuyas características no es ahora el momento de explicar. Pues bien, Jesús enseña que la mujer no es propiedad del varón, que pueda deshacerse de ella por cualquier motivo. Esto lo había permitido Moisés por la dureza de su corazón, pero "desde el comienzo de la creación Dios los hizo varón y mujer" y la voluntad de Dios era "que el hombre dejase a su padre y a su madre y se juntase a su mujer y formasen una sola carne. De manera que no son dos sino una sola carne. Y lo que Dios ha unido que no lo separe el hombre" (Mc 10, 4-9).

Más aún, Jesús prevé que, en algunos casos, y por su causa se dividirán trágicamente las familias (Lc 12, 52-53; Mt 10, 35-36; Mc 13, 12) ${ }^{10}$.

10. Sobre este tema, que suena chocante y hasta escandaloso a los ordos actuales muchas veces, pero que es central en el evangelio e inesquivable puede verse S. Guijarro, Fidelidades en conflicto. La ruprura con la familia por causa del discipulado y de la mision en la sradicion sinoprica, Salamanca, 1998. 
En segundo lugar, la riqueza, como ya to hemos observado antes, era para buena parte de la teología rabínica signo de la bendición divina. Para Jesús, por el contrario, es la gran dificultad para entrar en el reino de Dios. "Donde está tu tesoro allí está tu corazón" (Mt 7,21). Por eso, "no te hagas tesoros en la tierra, donde hay polilla y herrumbre que corroen, y ladrones que socavan y corroen" (Mt 7, 19). La verdadera sabiduría enseña: "vendan sus bienes y den limosna y tendrán un tesoro en el cielo, donde no llega el ladrón ni corroe la polilla" (Lc 12, 33). No hay mayor necedad ( $L c 12,20$ ), es decir, una falta de sabiduría más grande que pensar que a base de acumular riquezas y más riquezas se puede asegurar, de verdad, la propia vida (LC 12, 15-21).

En tercer lugar, en aquella sociedad teocrática y legitimada teológicamente, se llevaba el aparecer como una persona muy religiosa, hacer ostentación de religiosidad, de practicar la oración, el ayuno y la limosna, de hacer ofrendas muy generosas al Templo. Pero Jesús defiende una religión basada en la sinceridad de corazón, sin importarle lo que piensen los hombres (Mt 6, 1-18: "Cuando des limosna, ores o ayunes no lo hagas con ostentación como los hipócritas... Que tu mano izquierda no sepa lo que hace la derecha, que tu oración sea en lo secreto, úngete y pon cara alegre cuando ayunes... y tu Padre que ve en lo secreto te recompensará"). Sobre todo, afirma que no es auténtica la relación con Dios si no va acompañada de fraternidad con el prójimo (Mt 5, 23-24). Denuncia una religión con la que se pretende limpiar la conciencia, pero que se realiza al margen de la caridad y de la justicia. Lo expresa muy bien Mateo cuando pone dos veces en boca de Jesús la frase del profeta Oseas: "Misericordia quiero y no sacrificio" $(9,13 ; 12,7)$.

Por último, el honor" era el valor central de aquella sociedad y por tal se entendía la consideración que una persona gozaba a los ojos de los demás y que ella misma interiorizaba como la forma de verse a sí misma, en el seno de la sociedad. El honor dependra, fundamentalmente, de la familia de procedencia, es decir, era una cualidad adscrita al grupo social, que era el encargado también de velar porque el honor se mantuviese, lo que implicaba el control del comportamiento de los miembros del propio grupo y también la reacción contra quien, desde fuera, atentase contra él. Aunque el honor era, en principio, una cualidad de adscripción por nacimiento, en un determinado linaje, también podía ser aumentado con comportamientos honorables, como determinadas hazañas militares u obras de beneficencia, en favor de la comunidad, que reportaban un reconocimiento social. Es bien sabido que la forma de entender los comportamientos honorables, y su contrapartida, los vergonzosos, son muy diferentes, en el caso de las mujeres y en el caso de los varones.

11. B. J. Malina, El mundo del Nuevo Testamento. Perspectivas desde la antropología cultural, Estella, 1995, pp. 45-84. 
Jesús invierte la forma de entender el honor. He aquí algunos ejemplos. Pocas cosas hay más deshonorables que recibir una bofetada en la mejilla derecha (supone que la pegan por detrás o con el envés de la mano), sobre todo si es en público. La reacción que Jesús pide es la opuesta a la instintiva del honor ofendido. Nada de repeler la agresión, ni de retar al ofensor: "al que te abofetee en la mejilla derecha preséntale también la otra" (Mt 5, 39). Es una forma novedosa, que supone enorme autocontrol, de desarmar al agresor. En los banquetes y en las reuniones públicas, el honor se manifiesta en la ocupación de los lugares preferentes y, en su caso, más cercanos al anfitrión. Siempre ha sido una práctica común buscar los primeros puestos, también en tiempo de Jesús e, incluso, entre sus mismos discípulos (Mc 12, 39; Lc 14, 7-11; Mc 9, 34). La enseñanza alternativa de Jesús, en este punto, es particularmente abundante y significativa: "Si uno quiere ser el primero, sea el último de todos y el servidor de todos" (Mc 9, 35); "Cuando te inviten vete a ocupar el último puesto" (Mt 14, 10). Las personas tenidas por honorables son servidas por sus sirvientes, esclavos y clientes, pero Jesús dice: "el que quiera ser grande entre ustedes, será su servidor, y el quiera ser el primero entre ustedes, será esclavo de todos". Y, en efecto, Jesús asume él mismo, en un gesto simbólico de especial solemnidad, el papel del servicio más humilde, reservado para mujeres y esclavos (Jn 13, 1-15; Mc 10, 45: "El Hijo del Hombre no ha venido a ser servido sino a servir").

He evocado una serie de textos a los que podrian sumarse muchos más ${ }^{12}$ y que nos hacen ver que la puerta estrecha y el camino angosto significan promover y optar por unos valores alternativos, por una forma distinta de entender y vivir la existencia. Quizá se podría decir que implica solidarizarse con quienes se encuentran en situaciones consideradas poco honorables, pobres y estigmatizados socialmente, situaciones que pueden ser muy deshumanizadoras, pero que Jesús enseña a asumirlas como lugares donde puede germinar una verdadera y positiva altemativa cultural y moral ${ }^{13}$. La pobreza de espíritu, la no violencia, la limpieza de corazón, la misericordia, la construcción de la paz..., las actitudes de la enseñanza de Jesús son un camino de vida, que supone un distanciamiento crítico, respecto a lo establecido por la sociedad ${ }^{14}$, que exige una gran libertad interior, que nace, para Jesús, del enraizamiento en la experiencia de Dios. Jesús se encuentra, sin duda, en la tradición de la sabidurfa "subversiva" de Israel, representada por el Qohelet y, sobre todo, por el libro de Job y que se diferencia de manera notable de la sabiduría convencional de Proverbios y Ben Sira.

12. Un estudio más completo del tema del honor en el Evangelio de Mateo puede verse en J. H. Neyrey, Honor and Shame in the Gospel of Matthew, Louisville, 1998.

13. R. Aguirre, "Jesús, parábola de Dios Padre", en R. Aguirre, L. Mª Amendáriz, S. Del Cura, Dios Padre de Jesucristo, Cuadernos de Teología Deusto 22, Bilbao, 1999, pp. 19 s.; C. Gil, Los valores negados. Ensayo de exégesis socio-cientfica sobre la autoestigmatización en el movimiento de Jesús, Estella, 2003.

14. M. Borg, op. cir., pp. 115 ss. 
El angosto y la puerta estrecha es un camino de transformación personal's. Este es un punto decisivo, porque la sabiduría de Jesús no es algo teórico, sino una forma de vivir y busca cambiar el corazón del ser humano, su corazón sí, pero también sus manos y su cabeza; exige cambiar la mentalidad ("renuévense mediante la transformación de su mentalidad" dice Pablo, en Rom 12, 2), y cambiar la forma de actuar. Pero es, paradójicamente, un camino de vida, de felicidad y de plenitud. Es, por tanto, un camino de sabiduría y Jesús lo expresa con unas frases incisivas, Ilenas de verdad psicológica: "quien hace girar su vida sobre su propio yo la pierde, pero el que la entrega la gana" (Mc 8, 35); "hay más felicidad en dar que en recibir" (Hech 20, 35).

Para Jesús, la verdadera sabiduría introduce la vida en la dinámica del don, es decir, del amor gratuito, que no calcula en función del propio interés, que supera la ley de la mera reciprocidad. Su máxima expresión es el amor a los enemigos, éste es el amor que nos hace hijos de Dios, que nos identifica con Dios que - como dice Jesús, en una máxima de inconfundible sabor sapiencial - "hace salir su sol sobre buenos y malos, hace llover sobre justos e injustos" (Mt 5, 45).

\subsection{La raíz de la sabiduría de Jesús}

La gente se daba cuenta de que Jesús era un sabio, sus palabras les tocaban sus fibras más intimas, percibían su verdad y comprobaban con asombro la enorme libertad de aquel hombre. “Pero de dónde le viene esta sabiduría?", se preguntaban sus conciudadanos de Nazaret $(\mathrm{Mc} 6,2)$. Ellos conocían a sus hermanos y hermanas, sabían que era hijo de José y de María y que, por tanto, no tenía una autoridad tradicional, que le viniese de familia. Tampoco posera lo que se llama una autoridad legal, porque carecía de títulos académicos, no había frecuentado ninguna de las escuelas famosas de Jerusalén.

Sólo hay una respuesta para esta pregunta: la libertad de Jesús y la sabiduría de sus palabras proceden de su honda y peculiar experiencia de Dios. Los evangelistas lo declaran solemnemente, en el umbral de sus relatos, en unos acontecimientos (el bautismo para Marcos, la concepción por la fuerza del Espíritu, además del bautismo, para Mateo y Lucas), en los que ven la clave de toda la vida de Jesús, que narran a continuación: Jesús es un hombre que posee, en plenitud, el Espíritu de Dios.

Dios no es algo sobre lo que Jesús hable, sino alguien a quien siente presente en su interior, que se le hace patente en los acontecimientos y en el prójimo, y cuya presencia él evoca de forma inmediata, sencilla y profunda, porque le surge de dentro, como lo más real y valioso que sostiene su vida.

15. M. Borg, pp. 108-116. 
Termino esta primera parte con una breve alusión a un tema, cuyo recto planteamiento ayudaría a superar muchas dicotomías estrictas, que han polarizado la investigación, en tomo al Jesús histórico: no se puede establecer una separación estricta entre el Jesús sabio y el Jesús profeta ${ }^{16}$. Jesús anuncia el reino de Dios, que viene y que, incluso, está ya irrumpiendo, anuncia el alborear del nuevo dra, en que Dios va a cambiar todas las cosas y, por eso, cree que ya desde ahora se puede vivir de una forma diferente, más honda y más libre, viendo la realidad y la vida con la luz nueva y la sabiduría nueva, que procede de la presencia de Dios.

\section{Cristo Sablduría}

Tras su muerte y resurrección, sus primeros seguidores interpretaron a Jesús a la luz de la sabiduría de Dios, que el Antiguo Testamento vefa actuante en Israel. Nos encontramos con una de las interpretaciones más ricas, evocadoras y sugerentes, a la cual no se suele prestar la importancia que tiene. Me tengo que limitar a unas pocas indicaciones sobre algunos textos, sin presentar el tema de forma completa, ni mucho menos'?

\subsection{San Pablo: Cristo crucificado sabiduría de Dios}

Empiezo por san Pablo, por su texto más antiguo, impresionante por su audacia y hondura teológica. El tema de la sabiduría fue acuciante para Pablo cuando lleva la fe en Jesucristo a Asia Menor, a Grecia, a las grandes urbes como Atenas, Corinto, Efeso o Roma. En estas y otras ciudades existran acreditadas escuelas filosóficas y era continuo el trasiego de predicadores y maestros con sus discípulos. El prestigio de la sabidurla, en la civilización helenística, era enorme y se rivalizaba por ella. No era, ciertamente, fácil la tarea de Pablo de anunciar un Salvador, procedente de un oscuro rincón del imperio, miembro del extraño y conflictivo pueblo judío y que, encima, había sido crucificado por los romanos, sin que se hubiesen cumplido las expectativas, que un puñado de gente habia depositado en él. ¿Qué actitud adoptó Pablo? ${ }^{18}$.

16. D. Marguerat, "Jésus le sage et Jésus le propète", en D. Marguerat, E. Norelli, J. M. Poffet (eds.), Jésus de Nazaret. Nouvelles approches d'une énigme, Géneve, 1998, pp. 293-318.

17. M. Gilbert, J. N. Aletti, La sabiduria y Jesucristo, Cuademos Biblicos 32, Estella, 1981; P. E. Bonnard, "De la Sagesse personifiée dans l'Ancient Testament à la SBgesse en personne dans le nouveaux", en M. Gilbert (ed.), La sagesse de l'Ancient Testament, BETL 51, Leuven, 1990, pp. 117-149.

18. Como es claro, me refiero al Pablo que conocemos por sus cartas autenticas y no a la imagen lucana de Pablo de los Hechos de los Apostoles, que tiene una actitud más expresamente positiva, respecto a la sabidurfa griega, como se ve en el famoso discurso en el Arébago de Atenas (Hech 17). 
Pablo, por una parte, quiere hacerse entender y usa categorías de aquella cultura con la cual pretende dialogar (incluso en sus cartas recurre a procedimientos retóricos del tiempo), pero, por otra, adopta una postura crítica y polémica, porque subraya sin tapujos la novedad escandalosa de la fe cristiana.

Me voy a fijar en sus famosos y trascendentales capítulos 1 y 2 de 1 Corintios. Los interlocutores son cristianos, que tienen en muy alta estima a la sabidurfa y esto provoca divisiones y rencillas, en su pugna por ver quién era el más idóneo intérprete de la filosofía cristiana. Pues bien, Pablo establece una contraposición entre la sabidurfa del mundo y la sabidurfa de Dios. Y en la polémica no rehúsa formulaciones provocativas y escandalosas. Ante todo, reconoce que su apariencia no es la de un filosofo prestigioso, porque ni utiliza una retónica brillante, ni cuenta con el patronazgo de ningún mecenas rico. Parece que Pablo vivió siempre de su trabajo manual, lo que era un descrédito, en la concepción elitista del helenismo, pero que para el apóstol era clave para dejar claro su desinterés y, al mismo tiempo, le proporcionaba ocasión para entrar en contacto con quienes recurrían a sus servicios y con otros colegas, a la vez que, por su misma condición de trabajo tenido por servil, le identificaba con el contenido del mensaje del crucificado y servidor, que era la causa de su vida ${ }^{19}$. Esta situación está detrás de sus palabras: "Me presenté ante ustedes débil, tímido y tembloroso. Y mis palabras y mi predicación no tuvieron nada de los persuasivos discursos de la sabidurla, sino que fueron una demostración del Espíritu y del poder para que su fe se fundase, no en sabiduría de hombres, sino en el poder de Dios" (1Cor 1, 22-25).

A continuación, Pablo afirma que la sabiduría del mundo se entonteció. ¿Por qué? Porque no fue capaz de reconocer y aceptar la sabiduría de Dios, que se manifiesta a través de su creación. "El mundo, con su propia sabiduría, no reconoció la sabiduría de Dios" $(1,21)$. Y establece una contraposición entre lo tenido en el mundo convencionalmente por sabiduría y la sabiduría de Dios, que en el mundo es tenida por locura, escándalo, necedad y debilidad.

Mientras los judíos piden señales y los griegos buscan sabidurfa, nosotros predicamos a un Cristo crucificado, escándalo para los judíos, necedad para los gentiles; mas para los llamados, lo mismo judíos que griegos, un Cristo, fuerza de Dios y sabidurfa de Dios. Porque la necedad divina es más sabia que la sabiduría de los hombres, y la debilidad divina más fuerte que la fuerza de los hombres $(1,22-25)$.

Es decir, en Cristo crucificado se manifiesta la sabiduria de Dios, que supera a la sabiduría humana, una sabiduría no convencional, alternativa, que nos enseña a situar toda la realidad en un horizonte gratuito e insospechado. Cristo cruci-

19. R. Aguirre, Del movimiento de Jesús a la Iglesia cristiana. Ensayo de exégesis sociologica del cristianismo primitivo, Estella, 1998, pp. 166-176. 
ficado expresa, en su mismo ser y en su vida, la sabiduría de Dios. Pablo describe los rasgos de esta sabiduría como sigue:

Sin embargo, también nosotros tenemos una sabiduría para adultos en la fe, aunque no es una sabiduría de este mundo, ni de loś poderes que gobiernan este mundo y están abocados a la destrucción. De lo que hablamos es de una sabiduría divina, misteriosa, escondida, una sabiduría que Dios destinó para nuestra gloria antes de los siglos y que ninguno de los poderosos de este mundo ha conocido, pues de haberla conocido, no habrian crucificado al Señor de la gloria $(2,6-8)$.

Aquí, Pablo describe la sabiduría divina, que actúa en la persona de Jesús con rasgos que, en el Antiguo Testamento, son propios de la sabiduría personificada. Es divina (Prov 8, 22; Sir 24, 3), misteriosa, escondida, inaccesible (Job 28; Bar 3-4; Sir 1), preexistente, creada antes de los siglos (Prv 8, 23; Sir 24, 9), gloriosa (Sab 7, 25; 9, 10) y desconocida para los jefes de este mundo (Bar $3,16)^{20}$.

Para Pablo, Cristo crucificado no es la simple personificación de la Sabiduría de Dios, sino la manifestación de la forma de actuar de la Sabiduría de Dios, en el mundo. Y si los corintios están divididos y enfrentados, es porque se rigen por los valores de la sabiduría convencional y hegemonica del mundo y porque no han interiorizado la Sabidurfa de Dios, la verdaderamente humanizante, que no se basa en el honor, la riqueza y el poder, sino en el servicio, el desprendimiento y la gratuidad ${ }^{21}$.

\subsection{San Juan: la Sabiduría preexistente viene a nacer entre los hombres}

Es, sobre todo, el Evangelio de Juan el que explota con la profundidad que le caracteriza los motivos sapienciales para expresar la obra y la persona misma de Jesús. Si puede considerarse que algunos pasajes del Antiguo Testamento presentan la Sabiduría como una realidad personificada, Juan ve en Jesús la Sabiduría misma de Dios ${ }^{22}$. Me voy a fijar sólo en un texto, pero genial y bellísimo, el famoso prólogo del Evangelio, que es un himno que desarrolla todo el proyecto salvador de Dios ${ }^{23}$.

20. N. Calduch, "Jesús de Nazaret: Sofía de Dios", en I. Gómez Acebo (ed.), $Y$ vosorras, ¿quién decís que soy yo?, Bilbao, 2000, pp. $196 \mathrm{~s}$.

21. En la tradición pospaulina tiene especial importancia el himno de Col 1, 15-20, por su forma de relacionar a Jesús con la Sabiduria. Cfr. J. N. Aletti, Saint Paul: epirre aus Colossiens, Paris, 1993.

22. R. E. Brown, El Evangelio según San Juan, Vol. 1 - II, Madrid, 1979, pp. 141-146, 173-213, 1495-1503.

23. Además de la obra citada en la nota anterior y dentro de una bibliografia inmensa, me permito citar A. Jaubert El Evangelio seglin San Juan, Cuadernos Bíblicos 17, Estella, 1978, pp. 17-27. 
Voy a mostrar cómo, en este prólogo, el itinerario de Jesucristo, considerado el Logos, Palabra o Verbo de Dios, es descrito de forma semejante al itinerario de la Sabiduría, en el Capítulo 24 del Eclesiástico o Ben Sira, donde a su vez resuenan motivos de toda la literatura sapiencial.

En el principio existía la Palabra

y la Palabra estaba junto a Dios.

En Ben Sira, la Sabidurfa tenía su tienda en las alturas y procedía de la boca del Altúsimo. La Sabiduría estaba junto a Dios desde el principio, antes de que hubiera una tierra (Prov 8, 22-23; Sir 24, 9; Sab 6, 22).

La Palabra era la luz verdadera,

que ilumina a todo hombre que viene a este mundo.

La Sabiduría extiende sus dominios sobre todos los pueblos y naciones y busca una heredad donde descansar ( $\mathrm{Sir} 24,6-7$ ).

La Palabra vino a los suyos,

pero los suyos no la recibieron.

Esta repulsa de la Palabra se parece mucho al rechazo de la Sabiduría por los hombres, en Henoch 42, 2: "Vino la Sabiduría a establecer su morada entre los hijos de los hombres, pero no halló donde morar".

La Palabra se hizo came

y plantó su tienda entre nosotros.

La sabiduría, dice Ben Sira, puso su tienda en Jacob, se estableció en Sión. En mucho textos se afirma que la Sabidura descendió de los cielos para morar con los hombres.

De su plenitud todos hemos recibido.

La Sabiduría clama, en el Antiguo Testamento: vengan a mí todos los que me desean y sáciense de mis frutos.

Las semejanzas podrian multiplicarse y, concretamente, en el Capítulo 24 del Ben Sira, que he citado, la sabiduría se identifica con la Torá, con la Ley $(24,23)$. Para el judásmo, de la Torá viene la luz, que orienta en el camino de la vida. En el tratado Pirque Abot de la Misná se dice: "Grande es la Torá, porque da la vida a quien la observa en este mundo y en el venidero" $(6,7)$. Para Juan, la Sabiduría es Jesucristo: "es la luz verdadera que ilumina a todo hombre que viene a este mundo" $(1,9)$; y es también la vida y la vida eterna $(3,35 ; 11,25)$.

Pero sobre todo, y esto es lo más importante, la Sabidurfa no viene simplemente a habitar entre los humanos. Ahora, en Jesucristo, la Sabidurfa se hace came, sarx, carne en todo su sentido material, con su inevitable limitación. La Sabidu- 
ría infinita de Dios, preexistente desde siempre junto a Dios, se va a manifestar, a través de las palabras, obras y vida de Jesucristo.

Pero debemos preguntarnos: esta presentación de Jesús como Sabiduría divina, ¿es un desarrollo exclusivamente joánico o es posible rastrearla también en la tradición primitiva de los otros evangelios?

\subsection{Jesús como Sabiduría en los evangelios sinópticos}

Los evangelios sinópticos, en cuanto que son relatos de la vida de Jesús, le presentan como sabio y con una sabiduría muy peculiar, basada en su honda experiencia de Dios. Pero los sinópticos son unos relatos muy especiales, son relatos confesionales, que reflejan - aunque de forma más moderada que Juantoda una cristología.

En los sinópticos, Jesús es visto como el sabio de Dios e, incluso, como la sabiduría de Dios, que invita a los hombres, les envía sus mensajeros y les ofrece sus dones. Como en los parágrafos anteriores, también aquí me limito a una selección de textos.

En el primero, Mateo 12, 38-42, tremendamente polémico con los escribas y fariseos, que lo retan a que haga un signo, Jesús contrapone la actitud de "esta generación malvada y perversa", con la de los ninivitas, paganos, en oriente con fama de pecadores (pensemos en las diatribas contra Babilonia, en los profetas, o la forma tan peyorativa como es tratada en el Apocalipsis 18, que utiliza la maldad legendaria de esta ciudad para referirse a Roma), que, sin embargo, se convirtieron con la predicación de Jonás. "Y aqư hay algo más que Jonás", dice Jesús que se pone así, no ya en la serie de los profetas, sino por encima de ellos. Y después les contrapone a la reina de Saba, que vino desde su lejana tierra africana para oŕr la sabidurfa de Salomón (sabiduría festejada siempre como memorable). "Y aquí hay algo más que Salomón". Jesús se pone así como el cumplimiento trascendente de la sabiduría del Antiguo Testamento.

En Mateo 11, 28-30, Jesús invita a los hombres con el mismo tono y las mismas expresiones que la sabiduría del Antiguo Testamento:

Vengan a mí todos los que estén fatigados y agobiados, y yo los aliviaré.

Tomen sobre ustedes mi yugo, y aprendan de mi, que soy manso y humilde

de corazón; y hallarán descanso para sus almas. Porque mi yugo es suave y mi carga ligera.

En Ben Sira 6, 25-30 encontramos: "doblega la espalda y carga con la sabiduría" (25); "adorno de oro será su yugo (de la sabidurfa)" (30); "porque al final hallarás en ella descanso y ella se convertirá en tu alegría" (28).

Jesús es la Sabiduría divina, y su yugo, a diferencia del legalismo sofocante de las autoridades sinagogales, ofrece descanso a un pueblo fatigado y agobiado. 
Voy a fijarme ahora en un texto que se encuentra en Mateo 23, 34-36 y en Lucas $11,49-51 ; 13,34-35$, que con toda probabilidad procede de una fuente que ambos conocen y usan, la llamada fuente $Q$, antiquísima y testigo de una teología que presenta a Jesús como la Sabiduría de Dios. Jesús dice: "Dijo la Sabidurfa de Dios: les enviaré..." (así el texto de Lucas; en Mateo Jesús dice: "Yo les enviaré". Evidentemente, Jesús se está identificando con la Sabiduría); continúa Lucas: "Profetas y apóstoles, y a algunos los matarán y perseguirán..." (la continuación de Mateo es ligeramente diferente: "profetas, sabios y escribas, a unos, ustedes los matarán y crucificarán..."). En cualquier caso, se trata del conocido tema del rechazo de la Sabiduría de Dios, pero realizado con especial violencia y contumacia.

Este texto continuaba así, en la antiquísima fuente $\mathrm{Q}^{24}$ :

¡Jenusalén, Jerusalén, que matas a los profetas y apedreas a los que te son enviados! ¡Cuántas veces he querido reunir a tus hijos, como una gallina a sus polluelos bajo sus alas, y no han querido! (Lc 13, 31; Mt 23, 37).

La mayor dicha del fiel, en el Antiguo Testamento, es cobijarse "bajo las alas de Yahve"2s. La tradición sinóptica usa esta imagen para desarrollar la cristología sapiencial con un tema muy conocido: la Sabiduría escoge por morada Jerusalén (Sir 24, 8ss); invita a participar de su mesa (Sir 24, 19; Prov 9,1 ss), pero encuentra rechazo y se retira ( $c f r$. Prov 1, 24 ss). Para no cansar con más citas, reitero la ya presentada de Henoch, pero ahora de forma más amplia: "la sabiduría no encontró lugar donde morar, y fue su morada el cielo. Salió la sabiduría a morar entre los hijos de los hombres y no encontró aposento. Volvió la sabiduría a su lugar y se asentó entre los ángeles" (42).

Hay que notar que nos encontramos aquí con una imagen femenina y maternal, aplicada a la Sabiduría y luego a Cristo. Y esto nos da pie para abordar un último punto.

\subsection{La Sabiduría y una cristología con rasgos femeninos ${ }^{26}$}

Hemos visto que, para los sinópticos y Juan, Jesús es la Sabiduría de Dios. ¿Pero por qué Juan no le llama Sabidurfa, sino Logos (que se puede traducir por

24. Hay un gran debate sobre la colocación primitiva de esta perícopa y las opiniones están muy divididas, aunque probablemente son mayoría las que defienden que es Mateo quien conserva el orden primitivo de $Q$, que es la opinión que yo asumo. Pueden verse las diferentes opiniones con los argumentos en que se basan en J. $\mathrm{S}$. Kloppenborg, $Q$ Parallels. Synopsis, Critical Nores and Concordance, Sonoma, 1988, pp. 158 s.; cfr. también J. S. Kloppenborg, The Formation of Q: Trajectories in Ancient Wisdom Collection, Philadelpia, 1987, p. 227.

25. Sal 17,$8 ; 36,8 ; 57,2 ; 61,5 ; 63,8 ; 91,4 ;$ Dt 32,11 ; Rut $2,12$.

26. E. Schüssler Fiorenza, Cristología feminista crírica. Jesús, Hijo de Miriam, Profeta de la Sabiduría, Madrid, 2000. 
Verbo o por Palabra, que es la opción que he seguido en este artículo)? Conviene reparar en un dato importante: Sabiduría, tanto en hebreo (hokma) como en griego (sofia), es femenina. ¿Habrá buscado Juan un vocablo masculino en griego (logos, en efecto, es masculino, aunque en español lo traduzcamos por "palabra"), precisamente, porque Jesús es varón? ¿Pero no nos encontramos con una cristología de rasgos femeninos como conresponde a la Sofia-Sabiduría del Antiguo Testamento? ${ }^{27}$.

En la Sabiduría divina, dentro de un uso flexible y maleable de las palabras, se reflejan imágenes que se han atribuido, y no siempre de forma positiva, a las mujeres. La Sabiduría que los sabios de Israel intentaban plasmar en sus textos no es una persona humana, ni tampoco una diosa celestial, sino Dios mismo, que se comunica a los humanos en femenino ${ }^{28}$. Algunos autores han querido ver en la Sabiduría, sobre todo cuando aparece más o menos personificada, la asunción por parte del monoteísmo judío de la función que en algunos pueblos vecinos, especialmente en Egipto, se atribula a la divinidad femenina. Von Rad afirma: "no cabe la menor duda que los maestros israelitas se dejaron influir por la concepción egipcia de la diosa que presidía el orden del universo y llegaron incluso a reproducir algunas de sus expresiones linguísticas"29.

En Jesús, constatamos actitudes netamente antipatriarcales: dice que su misión es servir, lava los pies a otros, se le conmueven las entrañas reiteradamente ante la necesidad ajena, trata con mujeres tenidas por pecadoras... Si en aquella cultura patriarcal todo esto lo hubiese hecho una mujer, a nadie le habría llamado la atención. ¿No es esto lo que se supone que las mujeres hacen por naturaleza? Pero Jesús lo hizo desde su privilegio masculino y ahí estaba el problema y el escándalo ${ }^{30}$. Es indudable que nuestra cultura patriarcal se ha forjado un Dios varón, patriarcal, que, a su vez, ha legitimado el orden androcéntrico de la sociedad. Las cristologías del Hijo y del Logos han contribuido tambien a reafirmar el patriarcalismo, tanto en la visión de Dios como del orden social.

27. Hay un texto del Evangelio de los Hebreos, antiquisimo y judeocristiano, citado y comentado por Orígenes, en el que presenta audazmente al Esplritu como madre de Jesús. Las cursivas corresponden al texto del Evangelio de los Hebreos y el resto al comentario de Orígenes: "Y si alguien acepta el Evangelio de los Hebreos, donde el Salvador en Persona dice: Poco ha me tomó mi madre, el Espíritu Santo, por uno de mis cabellos y me llevó al monte sublime del Tabor, se quedará perplejo al considerar cómo puede ser madre de Cristo el Espíritu Santo, engendrado por el Verbo" (Origenes, In Jo. 2, 6: PG 14, 132C).

28. N. Calduch, art. c., pp. 193-194.

29. Citado por V. Morla, op. cir., p. 133. Morla presenta varios autores que desarrollan esta línea de pensamiento.

30. E. A. Johnson, La que es. El misterio de Dios en el discurso seológico feminista. Barcelona, 2002, p. 214. 
Pero nuestro hablar de Dios es imperfecto, analógico, está siempre necesitado de purificación. Cuando la Biblia habla de un Dios como Sabiduría, nos recúerda que Dios transciende las diferencias de género y que con tanta razón o sin razón podemos hablar de Dios como Padre o como Madre. R. E. Murphy dice: "La atrevida personificación de la Sabidurfa como mujer abre una grieta en el lenguaje que, condicionado por la cultura, habla de Dios de un modo completamente masculino"31.

De una forma semejante, el Jesús-Sofia-Sabuduría debe contrapesar al JesúsLogos-Hijo y contribuir a poner en su lugar los inevitables condicionamientos históricos, que tuvieron tanto el Jesús terrestre como sus discípulos, que formularon la primera cristología. Las particularidades históricas de la persona de Jesús lo único que hacen es confirmar que todas las personas existen, en sus particularidades históricas ${ }^{32}$. Esto ha sido siempre claro, respecto a su identidad étnica y social; sin embargo, se ha manipulado respecto a la identidad sexual, desembocando en el punto de vista de que lo masculino representa a Cristo mejor que lo femenino ${ }^{33}$. Jesús no fue negro, ni gentil, ni mujer, pero no hay ninguna razón para pensar que los blancos, los judíos y los varones tengan una capacidad mayor para identificarse con él y representar su misión.

El lenguaje teológico femenino de Cristo Sabiduría de Dios se desmarca de la masculinidad y nos ayuda a recuperar el significado total del acontecimiento de Cristo. La verdadera particularidad escandalosa que encontramos en Jesús es su opción por los pobres y marginados, movido por el Espíritu de Dios-Sabiduría compasiva ${ }^{34}$.

Bilbao, enero de 2004.

31. "Wisdom Literature and Biblical Theology", BTB 24 (1994), p. 7.

32. R. R. Ruether, "Feminist Theology and Spirituality", en Christian Feminism 21, citado por E. A. Johnson, p. 221.

33. E. A. Johnson, op. cit., p. 221.

34. E. A. Johnson, op. cit., p. 222. 